\title{
Greece: Searching for Light at the End of the Tunnel
}

As the familiar saga unfolds of another seemingly never-ending review and a looming deadline of debt payments ( $€ 7.4 \mathrm{bn}$ due in July), it is tempting to view the Greek crisis with a mix of déjà vu, exhaustion and resignation. Add anger and despair, since these are the prevalent emotions in Greek society as well - for good reasons, to be fair. The Greek economy has contracted every year since 2008 , with the sole exception of 2014. It has lost over a quarter of its $2008 \mathrm{GDP}$, comparable to the US Great Depression - except it has lasted twice as long.

After the economy bottomed out in 2011-12, the economy began to slowly recover. In spring 2014 the government accessed the markets with an oversubscribed bond issuance at a $4.95 \%$ yield; Greek banks issued bonds and attracted foreign investors, the formation of non-performing loans (NPLs) decelerated, and most macroeconomic indicators were improving. Institutional and market forecasts anticipated two years of strong growth. However, the January 2015 rise of SYRIZA, with its populist agenda of terminating the second bailout programme, reignited political risk. A highstakes game of chicken and political theatrics dominated the first semester of 2015, culminating in a plebiscite that made capital controls inevitable and threw the economy back into recession. Two additional years of negative growth followed, and the debt-to-GDP ratio moved into highly unsustainable territory. €25bn of bank equity value was irreparably lost for the Greek public shareholder when the stock market crashed following the introduction of capital controls, and a new round of recapitalisation for Greece's four systemic banks became inevitable in November 2015.

While it is easy to dismiss the Greek drama as a case of irresponsible government and self-destructive populism, one should pause and gauge the toll of the crisis. Between 2009 and 2016 real wages fell by a yearly average of $3.1 \%$; pensions have been cut 11 times since 2010; unemployment persists at $24 \%$, with youth unemployment at $46 \% ; 36 \%$ of the population is at risk of poverty or social exclusion; 450,000 Greeks have migrated abroad since 2008. Nearly 4 million taxpayers owe a total of $€ 93 \mathrm{bn}$ of unpaid taxes, 850,000 of whom have been subject to foreclosure.

Taking all that into account, the governing coalition between the radical left SYRIZA and the ultraright ANEL, united in their earlier anti-austerity populism, should come as no surprise. Far more prosperous societies have bred more reckless versions of populism. After the terrible summer of 2015, which led to the brink of Grexit, the Tsipras government buried its populist rhetoric, signed the country's third bailout programme, was re-elected to implement it and has been sticking to it ever since, with varying degrees of efficiency and commitment. Amidst the collapse of public confidence in both national and European institutions, there are some encouraging elements of resilience. The mainstream political party system is becoming increasingly mature in recognising that painful economic adjustment inside the eurozone is the country's only viable path. Greece's first bailout programme (2010) was approved by one party, the second (2012) by two, and the third (2015) by five parties. All parties represented in Parliament today (265 out of 300 seats) are pro-EU and pro-euro, except for the extreme-right Golden Dawn and the orthodox communist KKE. An unwavering majority of the public supports eurozone membership - though continued austerity will challenge this commitment.

Between 2009 and 2016, Greece implemented one of the largest fiscal adjustments in modern times, amounting to over 17 percentage points in cyclically adjusted primary balance terms. A vast array of reforms have been undertaken under the country's three successive economic adjustment programmes. And since signing the third programme, the Tsipras government has delivered, in fact overperformed, on its fiscal targets. The primary budget surplus achieved in 2016 is estimated at $2.0 \%$ of GDP, exceeding the programme target of $0.5 \%$. The programme targets for 2017 and 2018 are $1.75 \%$ and $3.5 \%$ respectively. 
Nonetheless, the ongoing second review of the third programme is now at a critical stage. While agreement to complete the review will most likely be reached soon, the review could also be added to a list of ambitious reviews that never concluded. The effort of the European creditors to retain full IMF participation (against the apparent reluctance of IMF staff and certain governments, including the new US administration) is the main factor complicating review conclusion.

The IMF is raising the bar for both sides. It is demanding that the Greek government provide more far-reaching reforms (with a focus on expanding the tax base and frontloading pension cuts) and that the European creditors accept lower primary surpluses post-2018 (i.e. closer to 2\% than 3.5\% of GDP) and provide bolder debt relief measures, since the IMF considers Greece's sovereign debt level to be highly unsustainable. A "global deal" is on the table, brokered by the Eurogroup presidency, but the effort to reach agreement on the specifics has proven difficult, especially given the persisting ambiguity over IMF participation.

One sticking point is the creditors' effort to establish a mechanism guaranteeing post-programme reform continuity. They insist that the Greek government pre-legislate additional fiscal measures of $2 \%$ of GDP for $2019-20$, consisting of pension cuts and a reduction of the income tax-free threshold from the current $€ 8,600$ to around $€ 6,000$. Electricity privatisation is another contentious issue, as is labour market reform, with disagreement between the Greek government and the IMF focusing on whether reform should abide by European or international "best practices".

Timely completion of the review is essential for ending the prolonged uncertainty in Greece and for the country to access the ECB's quantitative easing programme. This is vitally important for the Greek economy. It would reduce borrowing rates for the government and the private sector, giving banks a small profitability boost. It would improve credit ratings and confidence and reduce the number of NPLs. It would also permit the Greek government to proceed with gradual small bond issuances, with the objective of being able to access the markets by July 2018 , when the 3rd programme ends. Without the above sequence, Greece's economic recovery for 2017 would be suppressed or lost, and its banks could face severe recapitalisation needs in 2018. Inability or delay in accessing the market would render inevitable a fourth bailout programme, for which there is zero appetite in eurozone parliaments.

Thus, reason suggests the need for a speedy agreement by all sides on the grounds of enlightened self-interest to complete the review at the soonest possible. But reason has not always carried the day in the Greek crisis.

The delay of the review is already taking a toll on the economy. The economy contracted in the fourth quarter, turning the anticipated slightly positive growth for 2016 negative. Deposits are fleeing the banks again, NPLs are rising, dependence on ECB emergency liquidity assistance is growing and confidence indicators are deteriorating. The roadmap for the gradual easing of capital controls will be delayed, and there is a risk that they could instead be further strengthened.

The last thing both Greece and the EU want is another round of brinkmanship and another replay of the Greek drama. The country desperately needs a sense of stability and a year of recovery to be able to see some light at the end of the tunnel. This will be necessary to allow the adjustment effort to continue. A combination of credible debt reprofiling and productivity-enhancing reforms would allow the economy to target feasible primary budget surpluses without stifling growth. In the medium to longer run, the rebalancing of the economy will have to continue, with greater reliance on investment and exports to fill the gap from lower public and private consumption. This will allow the economy to gradually overcome the painful legacies of depression, including farreaching disinvestment and the erosion of productive and human capital via crippling long-term unemployment. Given time and stability, the most extreme case of adjustment inside an imperfect currency union could eventually become a case study for the positive transformative power of an ever deepening European economic and monetary union.

George Pagoulatos, Athens University of Economics \& Business, Greece; and College of Europe, Bruges, Belgium. 